\title{
Green Victimology Perspective the Law Number 32 of 2009 on Environmental Protection and Management
}

\author{
Angkasa \\ Faculty of Law, Universitas Jenderal Sudirman, Indonesia \\ E-mail: drangkasa_64@yahoo.com
}

\begin{tabular}{l} 
ARTICLE INFO \\
\hline Keywords: \\
green victimology; \\
ecocentrism; \\
anthropocentrism; \\
environmental harm \\
How to cite: \\
Angkasa. (2020). Green \\
Victimology Perspective \\
the Law Number 32 of \\
2009 on Environmental \\
Protection and \\
Management. Jurnal \\
Media Hukum, 27(2), 217- \\
228 \\
Article History: \\
Received: 02-10-2020 \\
Reviewed: 02-12-2020 \\
Revised: 19-12-2020 \\
Accepted: 31-12-2020 \\
\end{tabular}

\section{Introduction}

Christopher Williams' publication in 1996 which reviewed environmental victimology and included environmental harm as part of victimological study can be considered as the emergence of the soc-called green victimology. The inclusion of environmental harm as the object of the study of victimology is a new development. ${ }^{1}$ This new concept differs from the existing study that focuses on humans as its object suffering from victimization due to criminal action of others. It can be seen from various theories

\begin{abstract}
Green victimology refers to the study of victimology that focuses on victims of environmental harm. The object of this new study cannot be separated from the philosophical values that underlie the growth of green victimology. Through literature research based on secondary data, this research focuses on two studies. The first is about the philosophical foundations of green victimology and the second is about the perspective of green victimology in the Law Number 32 og 2009 on Environmental Protection and Management. Based on the results of the research, it can be stated that the foundation of green victimology ecocentrism which sees that the environmental entities have intrinsic value in virtue of their own interests apart from its instrumental or utilitarian value for humans. This is different from the values underlying the previous victimological study that was based on anthropocentrism. Ecocentrism has been adopted in the Law Number 32 of 2009 on Environmental Protection and Management.
\end{abstract}

DOI: 10.18196/jmh.20200153

Copyright @ 2020 JURNAL MEDIA HUKUM. All rights reserved.

\footnotetext{
${ }^{1}$ Melanie Flyn \& Matthew Hall, M said that during the last twenty years, Victimology as the study of victims of crime and victimization has grown rapidly, however, like criminology as the mother of victimology, there is very little discussion of environmental victimization. Flyn, M. \& Hall, M. (2017). The case for a victimology of nonhuman animal harms Contemporary JustiCe review, 2017 https://doi.org/10.1080/10282580.2017.1348898
} 
that limit the scope of victim only in regard to criminal activities as proposed by Separovic as follows:

Victims are the person who are threatened, injured or destroyed by an actor or omission of another (mean, structure, organization, or institution) and consequently; a victim would be anyone who has suffered from or been threatened by a punishable act (not only criminal act but also other punishable acts as misdemeanours, economic offenses, non fulfilment of work duties) or an accidents. Suffering may be caused by another man or another structure, where people are also involved. ${ }^{2}$

According to him, the victim is anyone who is threatened, injured or mistreated, due to the actions of other parties, whether intentional or due to accident or negligence. The other party are referred to a person, a structure, an organization, or an institution. Furthermore, what is also considered a victim is someone who suffers a loss in which the loss arises as a result of an act which is punishable by punishment (not only a serious criminal sentence, but also other acts in the form of minor offenses, economic violations) or a situation which cause an accident. This suffering may also be caused by a person or because of a system which is run by the people.

Green victimology suggests broder definition of victim that includes also victimization by the non-human actors such as animals, trees and rivers. ${ }^{3}$ Green victimology is, therefore, related to the eco justice perspective such as environmental justice with humans as the victims, ecological justice with animals as well as plants as the victims, and species justice where the victims are animals and vegetation. ${ }^{4}$ Thus, the orientation of green victimology is actually focused on victims of environmental harm. In line with this, White suggests that green victimology refers to the study of the social processes and institutional responses pertaining to victims of environmental crime". 5

In the past, as comparison, environmental harm has been ignored socially, culturally and legally underestimated as if there are no victims. ${ }^{6}$ This because the impact of environmental harm can not be instantaneously seen and sometimes can last a very

\footnotetext{
2Separovic, Z. P. Victimology, p. 29.

${ }^{3}$ This viewpoint is the same as Cullinan's viewpoint, which states that "Rivers, mountains, animals and plants, and specific ecosystems, for instances, can all be considered 'victims' in particular circumstances". Cullinan C, 2003, Wild Law: A Manifesto for Earth Justice. New York: Cyber Ink and Green Books. Stone uses the term natural object for naming the types of non-living victims such as rivers, mountains and seas. Stone C, 1972, Should trees have standing? Toward legal rights for natural objects. Southern California Law Review 45: 450-487

4 White, R. (2018). International Review of Victimology 1-17, Reprints and permission: $\begin{array}{llll}\text { sagepub.co.uk/journalsPermissions.nav } \quad \text { DOI: } & 10.1177 \quad \text { / } & 0269758017745615\end{array}$ journals.sagepub.com/home/irv

In another paper, White also revealed about the three groups of victims related to environmental victims which are associated with the intrinsic value of each victim group as follows.

Environmental justice - the victim is humans environmental rights are seen as an extension of human or social rights so as to enhance the quality of human life, now and into the future;

Ecological justice - the victim is specific environments human beings are merely one component of complex ecosystems that should be preserved for their own sake;

Species justice - the victim is animals, and plants animals have an intrinsic right not to suffer abuse, and plants not to suffer the degradation of habitat to the extent that threatens biodiversity loss. White 2013, Environmental Harm: An Eco-Justice Perspective. Bristol: Policy

${ }^{5}$ White, R. (2015). Environmental victimology and ecological justice. In: Wilson D and Ross S (eds) Crime, Victims and Policy: International Contexts, Local Experiences. Basingstoke: Palgrave Macmillan, pp. 33-52.

${ }^{6}$ Hall (2013). Victims of Environmental Harm: Rights, Recognition and Redress Under National and International Law. London: Routledge.
} 
long time and are even difficult to detect. In certain phenomena, the government also let the activities to take place for the purpose of industrial growth and the country's economic growth. ${ }^{7}$ As stated by Walter, environmental harm in some places is often caused by a lawful activity, and also justified by the political power due to financial benefits, or even promoted by the state. ${ }^{8}$ But ironically, several studies show that the victims of the environment harm are people on low incomes. ${ }^{9}$

Lack of attention to victims of environmental harm cannot be separated from the character of the victims of environmental harm as stated by Skinnider as follows:

a. The victims are not always aware of the fact that they have been victimized.

b. The victimization is often delayed, with the victim becoming aware of the victimization much later.

c. Victims are not sure about who victimized them or who exactly is responsible.

d. The victimization is often serious-not so much because any individual victim was seriously affected, but because numerous victims were affected by the crime.

e. Victimization can often include repeat offenses. ${ }^{10}$

Based on Skinnider's opinion, the absence or slow response of victims due to environmental harm is caused by the fact that they are not aware of the fact that they have actually become victims. In addition, environmental victimization is often seen or felt in the future when the victims finally realize that they have been victimized.

This is inseparable from the nature of environmental harm, in which the impacts are not immediately recognized. Victims often do not know the perpretrators or who are responsible for the victimization. This cause the victim does not understand how to submit the report. The victimization of the environment is a serious matter not because of its large impact, but because of the (large) number of victims. Victimization can also be in the form of repeat offenses.

Even in certain communities, they do not consider that they have become victims of environmental harm. This may have implications for government not to criminalize such activities. It also does not become the study of victimology which tends to focus on victims of victimization or conventional crimes. ${ }^{11}$

The emergence of green victimology cannot be separated from the development of issues in the 21st century regarding "green" and "environmental harm" ${ }^{12}$ Christopher

7 Compare this with Schnaiberg's view which also states that there are countries that give up environmental damage in order to facilitate the progress of a company's production (Schnaiberg, 1980, The Environment: From Surplus to Scarcity. New York: Oxford University Press).

${ }^{8}$ Walters, R. (2006). Crime, bio-agriculture and the exploitation of hunger. British Journal of Criminology 46 (1): pages 26-45.

${ }^{9}$ Lynch, M. J., McGurrin, D., \& Fenwick, M. (2004). Disappearing act: The representation of corporate crime research in criminological literature. Journal of Criminal Justice, 32 (5), 389-398.

10Skinnider. (2011). Victims of Environmental Crime - Mapping the Issues. Vancouver: The International Center for Criminal Law Reform and Criminal Justice Policy.

${ }^{11}$ Compare with the opinion of Skinnider, 2011, Victims of Environmental Crime - Mapping the Issues. Vancouver: The International Center for Criminal Law Reform and Justice Policy. Thing. 2

${ }^{12}$ Compare this with Matthew Hall's opinion which states that "The study of environmental victimization has been notably absent from the vast majority of academic and policy discussions surrounding victims of crime, despite the growing prevalence of 'green' issues and 'environmental harms' in the 21st century . Matthew Hal, 2013 Environmental harm and environmental victims: Scoping out a 'green victimology' 
William said that the impact of environmental crime, or environmental harm activities, has received rare attention in the mainstream of victimology literature. The purpose of using environmental victimology and entering the realm of green victimology is in order to overcome environmental victimization. ${ }^{13}$

In order to overcome the environmental victimization, it is important to provide an understanding to lawmakers about the dangers of the impact caused by environmental victimization. In certain circumstances, criminalization should be carried out. It can also be done by providing an idea or study to build a system in order to reduce the suffering of victims. There is an interesting aspect in green victimology related to the philosophical basis when constructing the victim which includes both ecocentric and anthropocentic values. This aspect will be the object of the research discussion.

Furthermore, the philosophical value in green victimology is used to examine the Indonesian laws and regulations related to the Environment, in this case Law Number 32 of 2009 on Environmental Protection and Management. This study has important means to measure what philosophical values are used by these laws and regulations in formulating environmental harm.

The novelty of this paper is a study of the development of victimology which does not only look at the scope of the study but the philosophical values that contain there in. In addition, it is also an analysis of the positive laws in the environmental sector, whether the values contained are in accordance with the development of world civilization.

\section{Method}

This research is conducted based on library research. In which the data source is in the form of secondary data from reputable scientific journals as well as research results and related reference books. Secondary data in the form of statutory regulations are also used, especially Law Number 32 of 2009 on Environmental Protection and Management. Victimology theory is used as an analysis tool.

\section{Analysis and Results}

\subsection{The Philosophical Basis of Green Victimology.}

Green Victimology focuses on victims of environmental harm in which there are human, ecological and species components that are interwoven in the ecosystem. According to Christopher Williams, environmental victims are:

“... Those of past, present, or future generations who are injured as a consequence of change to the chemical, physical, microbiological, or psychosocial environment, brought about by deliberate or reckless, individual or collective, human act or omission. ${ }^{14}$

International Review of Victimology 2014, Vol 20 (1) 129-143 ${ }^{a}$ The Author (s) 2013 Reprints and permission: sagepub.co.uk/journalsPermissions.nav DOI: 10.1177 / 0269758013508682

13 Williams, C. (1996). An environmental victimology. Social Science 23 (1): 16-40. Reprinted in: White R (2009) Environmental Crime: A Reader. Cullompton: Willan Publishing, 200-222.

14 Christopher William, 1996, An environmental victimology. Social Science 23 (1): 16-40. Reprinted in: White R (2009) Environmental Crime: A Reader. Cullompton: Willan Publishing, 35. 
Based on William's opinion above, it can be interpreted that environmental victims are those from past, present, or future generations who are injured or harmed as a result of changes in the chemical, physical, microbiological, or psychosocial environment, caused by intention or as a result from reckless action, committed by individuals or collective actions, or as a result of acts or negligence by humans. "

According to Hiskes' view, that definition creates justice between generations. ${ }^{15}$ Furthermore, in Williams' view, there is also the use of the word "injured" which is seen as more appropriate than using the word "harm". According to Williams, it can contribute to victimology as a starting point for the development of environmental victims who can contribute to the legal system and the criminal justice system to become more objective in measuring the value of environmental victims.

The viewpoint used by green victimology by including the environment as a victim is an ecocentric view. Ecocentrism, in Preston's view, sees the environment as a figure that has value for its own interests regardless of its instrumental or utilitarian value for humans. ${ }^{16}$ In Schlosber's view, eco-centrism sees the animals, plants and rivers having intrinsic value which must be properly respected. ${ }^{17}$ Intrinsic value can also be interpreted as a value that refers to the ethical value or value possessed by an object in itself or its own interests.

In this sense, an object with an intrinsic value has the right to be itself. ${ }^{18}$ One of the countries that has granted the rights to non-human subjects is Ecuador. Since 2008, Ecuador has regulated the natural rights' within its constitution. In which according to this constituion, nature or Pachamama has the right to exist, survive, reproduce, and maintain a vital regeneration cycle, structure, function. and the process in evolution. ${ }^{19}$

Ecocentrism is a new perspective and different from the old perspective which is widely used as a philosophical basis for legal development which has an impact on legal construction and criminalization in the scope of criminal law, namely the anthropocentric view. Anthropocentric emphasizes the values of human interests in the sense of prioritizing human interests over non-human interests. ${ }^{20}$ In an anthropocentric view, it is seen as environmental harm when it affects the interests of humans. ${ }^{21}$

It is true that different philosophical foundation can affects the formulation of the article in laws and regulations. The anthropocentric view in the environmental law, for example, environmental pollution can be criminalized when human actions on environment can threaten human health. it is limited to the interests of humans and it does not consider the interest of the animals. In this context, the question and the consideration why some species are given the protection while others are not can be

${ }^{15}$ Hiskes. (2008). The Human Right to a Green Future: Environmental Rights and Intergenerational Justice. Cambridge: Cambridge University Press.

16Preston. (2011). The use of restorative justice for environmental crime. Criminal Law Journal 35: 136-145.

${ }_{17}$ Schlosberg. (2007). Defining Environmental Justice: Theories, Movements, and Nature. Oxford: Oxford University Press.

18 Williams, C. (2013). Wild law in Australia: Practice and possibilities. Environmental Planning and Law Journal, 30, 259-284.

${ }^{19}$ Walters, B. (2011). Enlarging our vision of rights: The most significant human rights event in recent times? Alternative Law Journal, 36 (4), 263.

${ }^{20} \mathrm{Lin}, \mathrm{A}$. (2006)., The unifying role of harm in environmental law. Wisconsin Law Review, 3, 898-985.

${ }^{21}$ De Lucia. (2015), Competing narratives and complex genealogies: The ecosystem approach in international environmental law. Journal of Environmental Law, 27 (1), 91. 
answered. ${ }^{22}$ As example is the protection of apes in New Zealand and the Balearic Islands. ${ }^{23}$

In some jurisdictions, indigenous peoples who hunt traditionally or conventionally are exempt from prosecution for for the cruelty to animals. ${ }^{24}$ This also happens in Indonesia, in which in order to produce meat, the animals are killed in certain ways so that their blood does not come out. This can be seen as animal torture.

In practice, animals can be treated vary depending on their importance as White argues as follows.

1. being homeless: shelters frequently only take animals for a specified period of time, after which they are killed;

2. for entertainment: this includes events such as cock fighting, dog fighting and the blooding of greyhounds for racing and recreational fishing;

3. for food: not only mass production and factory farming, but also specific religiously prescribed procedures for killing animals that may be inherently problematic and cruel;

4. for military and policing purposes: putting dogs and other animals at risk in war and civil policing operations;

5. for collection: private trafficking and containment of exotic animals; and the treatment of animals by staff and by the public in circuses and zoos;

6. for pleasure: the abuse of animals for sexual gratification, such as bestiality, and including bestial pornography involving humans and non-human animals; and

7. for service and sale: the mass production of animals, for example in the form of 'puppy mills', in which excessive numbers of animals are quarantined in order to maximize breeding and the sale of offspring. ${ }^{25}$

In addition, the arrangement tends to use anthropocentric approach. Wyatt states that there is different treatment to the animals in the sense that there are animals that are exploited and harmed, and some are protected and respected based on legal norms, so a hierarchy of victims model is created related to environmental victims, all of which originate from an anthropocentric view. ${ }^{26}$

The view of eco-centrism is different from the anthropocentric view, in which in order to construct an environmental crime, the environment harm should done or cause by human action, for example a river becomes unable to flow anymore crreating the existing ecosystem dead or changes.

\footnotetext{
22 Herbig, J. \& Joubert, S. (2006). Criminological semantics: Conservation criminology - vision or vagary? Acta Criminologica, 19(3), 88-103.

23 Taylor, R. (2001). A step at a time: New Zealand's progress toward hominid rights. Animal Law Review, 7, 35-43

24 Voiceless. (2009). The animal law toolkit. Available at:www.voiceless.org.au (accessed January 25, 2020)

25 White, R. (2016). Inter-species violence: Humans and the harming of animals. In: Stubbs J and Tomsen S (eds) Australian Violence: Crime, Criminal Justice and Beyond. Sydney: The Federation Press, pp. 176-193.

26 Wyatt, T. (2013). Wildlife Trafficking: A Deconstruction of the Crime, the Victims, and the Offenders. Basingstoke: Palgrave Macmillan.
} 
In the other hand, if the anthropocentric approach is used as the philosophical basis, there will be no legal protection for the environment. This is due to not being able to reach the dangers and consequences caused and experienced by the environment, especially ecology and species. ${ }^{27}$ Proper protection of the natural environment can be based on the rights of nature both as a subject and object that deserves to be protected and respects its intrinsic value which makes humans obliged to protect it. ${ }^{28}$

In Pretone's view, the biosphere and non-human biota have independent intrinsic value of their utilitarian or instrumental value for humans. When harmed by environmental crimes, the biosphere and non-human biota can also be classified as victims. The losses can be assessed from an ecological perspective; it is not necessary to look at the losses suffered by humans as in an anthropocentric perspective. ${ }^{29}$ However, in court practice there are difficulties in measuring the value of losses that can be assessed from various perspectives, for example recreational value, historical value, or aesthetic value. ${ }^{30}$

Green victimology which has expanded the object of victims in terms of the environment and based on the value of eco-centrism, which means that recognizing the intrinsic values of each object can contribute to the protection of environmental harm. It can be exemplified as applied in European countries by determining the value of fines (restitution) against someone who illegally trading endangered species. ${ }^{31} \mathrm{In}$ addition, there is an opportunity for an expert to be questioned in court about the suffering of the victim (non-human victim) and the subsequent consequences of victimization, as stated in the Victim Impact Statement of the victim in court proceedings in England. ${ }^{32}$ The expansion of the victim's object has implications for the expansion of criminalization which leads to criminal law which is also a reflection of the expansion of moral values. ${ }^{33}$ However, with the help of criminal law enforcement which is based on the new moral values, it can reduce the danger or loss of ecosystem damage. ${ }^{34}$

A new moral values that have implications for a new scope will foster and create new rights, in this case the ecosystem. The result is legal protection for them and the implication is to minimize the victimization of the environment as a victim by imposing the sanctions, especially criminal law sanctions. ${ }^{35}$

${ }^{27}$ Flyn, M. \& Hall, M. (2017). The case for a victimology of nonhuman animal harms. Contemporary Justice review, 2017 https:/ / doi.org/10.1080/10282580.2017.1348898

${ }^{28}$ Fisher. (2010). Jurisprudential challenges to the protection of the natural environment. In: Maloney M and Burdon $P$ (eds) Wild Law - in Practice. London: Routledge, 95-112

29Preston. (2011). The use of restorative justice for environmental crime. Criminal Law Journal, 35: 143.

30 Olszynski, M. (2005). The Assessment of Environmental Damages Following the Supreme Court's Decision in Canfor. Journal of Environmental Law and Practice, 15-3, 257

${ }^{31}$ Garstecki. (2006). Implementation of Article 16, Council Regulation (EC) No. 338/97, in the 25 member states of the European Union. A TRAFFIC Europe Report for the European Commission, Brussels, Belgium. Cambridge: TRAFFIC Europ

${ }^{32}$ Hall. (2009). Victims of crime: Policy and practice in criminal justice. Cullompton: Willan Publishing.

${ }^{33}$ Wellsmith, M. (2011). Wildlife crime: The problems of enforcement. European Journal on Criminal Policy and Research, 17, 125-148.

${ }^{34}$ Nurse, A. (2012). Repainting the thin green line: The enforcement of UK wildlife law. Internet Journal of Criminology. Retrieved March 30, 2014, from https://www.internetjournalofcriminology.com/ Nurse_Repainting_The_Thin_Green_Line_IJC_Oct_2012.pdf

${ }^{35}$ Hall, M. (2014). Environmental harm and environmental victims scoping out a 'green victimology'. International Review of Victimology, 20 (1), 129-143. 
3.2. Green Victimology Perspective in the Law Number 32 of 2009 on Environmental Protection and Management

Law Number 32 of 2009 on Protection and Management of the Environment (UUPPLH) State Gazette of the Year 209 No. 140 is the main source of environmental law in Indonesia which regulates various aspects of the environment. This law is in lieu of Law No. 23 of 1997 concerning the Environment (UULH 1997) and UULH 1997 are the substitutes for Law No. 4 of 1982 concerning Basic Provisions for Environmental Management (UULH 1982).

UUPPLH consists of 127 articles 17 chapters, which consist of a preamble, general explanation and article's explanation. The perspective of green victimology on UUPPLH is based on the green victimology which mainly includes the environment that related to environmental justice, ecological justice and species justice. These three types of justice recognize that each person has a value for his own interests regardless of the instrumental or utilitarian value for humans. This value is known as intrinsic value as the character of eco-centrism which is a development from the previous philosophical foundation, namely anthropocentric.

To recognize the characteristic of a regulation, it is important to look at its considerations. Because the purpose of the norms and the implied aspects are contained there. The preamble also reflects the political standing that chosen by the makers of the legal norms. The articles furthermore constitute the implementation of legal politics and the purpose of the creation of that legal norm.

The preamble of UUPPLH letter a formulates: that a good and healthy environment is the basic right of every Indonesian citizen as mandated in Article $28 \mathrm{H}$ of the 1945 Constitution of the Republic of Indonesia. It can be seen that the main consideration in making this law is based on human interests (anthropocentric). . However, the preamble letter $d$ shows that there are other concerns other than humans, which states "... the decreasing quality of the environment has threatened the continuity of human life and other living things, so it is necessary to protect and manage the environment seriously and consistently by all stakeholders. The philosophical foundation in this formulation is already in the ecocentric direction which is emphasized by the word "... and other living things ...". Furthermore, in the letter $f$, it can be seen that the formulation in a balanced manner pays attention to the interests of humans and their ecosystem as their support. This includes the words: "... providing protection for the right of everyone to have a good and healthy environment as part of the protection of the entire ecosystem". Based on above preconceived formulations, it appears that the UUPPLH is already in an ecocentric position.

Furthermore, articles that contained in the UUPPLH also reflect the ecocentric philosophy. This is reflected by the formulation of Article 1 point 1 regarding the environment, "... and the welfare of humans and other living creatures". The word welfare of humans and other living things shows that the concern is not only humans but also other creatures. This also can be found in Article 1 point 21 which states: "... and/ or endangers the environment, health, and the continuity of humans and other living creatures". The word "the continuity of humans and other living things" also shows the appreciation of the intrinsic value of living things other than humans, which categories as eco-centrism. 
Article 3 UUPPLH formulates the objectives of this law and shows the perspective of the legislators and their political will. The formulation contained in several letters indicate an ecocentric view. Article 3 UUPPLH letter a, letter b, letter c, and letter d, for instance. Letter a states that "protecting the territory of the Republic of Indonesia from environmental pollution and / or harm"; letter b states that "guarantee the safety, health and life of humans; letter c states that "ensure the continuity of living things and the preservation of ecosystems; and letter $\mathrm{d}$ states that "preserving environmental functions. The word "territory" is clearly not only related to human interests. The word continuity of living things and ecosystem preservation is not only oriented to human interests.

Another article that shows an ecocentric perspective is related to the analysis of environmental impacts, abbreviated as AMDAL. This can be seen from the parameters regarding the impact as summarized in Article 55 UUPPLH. The criteria used to determine AMDAL are the impact on = other environmental components that will be affected by \{Article 5 paragraph (2) letter $d$ UUPPLH\}.

Based on the above discussion, it can be stated that the philosophical values contained in the UUPPLH are a combination of anthropocentric and ecocentric. Anthropocentism is seen in the protection of human interests, while ecocentric can be seen in the protection outside humans which in this case is related to ecological justice and species justice.

A philosophical model that simultaneously uses both anthropocentric and ecocentric is not wrong. This is in accordance with the opinion of Donnelly and Bishop who states that mankind is obliged to respect the nature but on the other hand and at the same time humans have the right to benefit from nature. Nevertheless, the instrumental use of nature for the benefit of humans remains within the corridor of ecocentric considerations in order to minimize the damage that occurs during the process of using or utilizing nature. ${ }^{36}$

Eckersley's opinion is also relevant to that opinion which states that humans have the same rights to live and develop as other species which tend to interfere with the existence of other creatures and other species' habitats. However, a wise effort according to an ecocentric viewpoint is to minimize the danger or risk outside of humans in this case in the context of ecology and species and on the other hand optimize the way so that ecology and species can develop in accordance with their respective ways or nature. ${ }^{37}$

The UUPPLH also contains some articles which regulate the legal protection for the victims. The Legal protection is the rights given or owned by every legal subject or environment based on the laws and regulations. ${ }^{38}$ The legal protection of the environment in that provision show that there is sustainability of environmental processes and functions; environmental productivity and sustainability; and safety,

36Donnelly, B. \& Bishop, P., (2007). Natural law and ecocentrism. Journal of Environmental Law, 19 (1), 89

37Eckersley. (1992). Environmentalism and Political Theory: Toward an Ecocentric Approach. New York: State University of New York Press

38The concept of legal protection is at the same time an extension of the concept of legal protection that I have stated in the book Victimology. Whereas legal protection is a right given or owned by every legal subject based on the prevailing regulations. This also indicates that green victimology has expanded the values that need to be protected. Not only human interests but also the environment for which its intrinsic value has been recognized. 
quality of life, and community welfare. This is related to the utilization of the environment as formulated in Article 12. There is also legal protection for the environment against environmental pollution and/ or harm carried out in the framework of preserving the functions of the environment through control as formulated in the Article 134 of UUPPLH such as prevention; management and restoration.

The clear and concrete legal protections for the environment can also be found in Article 15 UUPPLH. ${ }^{39}$ Several prohibitions are also imposed to prohibit a person from taking certain actions against environment in order to prevent environmental harm as regulated in the provisions of Article 69 paragraph (1) and paragraph (2) UUPPLH. Furthermore, in order to strengthen or improve the effectiveness of law enforcement and the implementation of legal protection for the environment, the sanctions for parties who take actions that cause environmental harm are also imposed.

This law also empowers administrative law, civil law and criminal law. However, of the three forms of law that can contribute directly to victims of environmental harm is through civil law with lawsuits mechanism. This mechanism allows the compensation to be imposed as the sanction. This is as regulated in the article 87 UUPPLH and known as polluter pays principle.

\section{Conclusion}

Based on the discussion above, it can be concluded that the philosophical basis of green victimology is eco-centrism. The perspective of green victimology in the Law Number 32 of 2009 on Environmental Protection and Management shows that in order to construct the environmental harm and the limitation of victims should be based on ecocentric approach. This is broaden the concept of legal protection for victims not only for the legal subjects but also for the environment.

\section{References}

Book:

Eckersley, (1992). Environmentalism and Political Theory: Toward an Ecocentric Approach. New York: State University of New York Press.

Fisher (2010). Jurisprudential challenges to the protection of the natural environment. In: Maloney M and Burdon P (eds) Wild Law - in Practice. London: Routledge ,.

Garstecki, (2006). Implementation of Article 16, Council Regulation (EC) No. 338/97, in the 25 member states of the European Union. A TRAFFIC Europe Report for the European Commission, Brussels, Belgium. Cambridge: TRAFFIC Europe

Hall. (2009). Victims of Crime: Policy and Practice in Criminal Justice. Cullompton: Willan Publishing.

Hall. (2013). Victims of Environmental Harm: Rights, Recognition and Redress Under National and International Law. London: Routledge.

\footnotetext{
39 Article 15 paragraph (1) UUPPLH formulates that Article 15 (1) Government and local governments are obliged to make KLHS to ensure that the principles of sustainable development have become the basis and are integrated in the development of an area and / or policies, plans, and / or programs.
} 
Hiskes (2008). The Human Right to a Green Future: Environmental Rights and Intergenerational Justice. Cambridge: Cambridge University Press.

Schnaiberg. (1980). The Environment: From Surplus to Scarcity. New York: Oxford University Press.

Separovic, Z. P. (1974). Victimologi a New Approach in the Social Science. Victimology a New Focus.

Skinnider. (2011). Victims of Environmental Crime - Mapping the Issues. Vancouver: The International Center for Criminal Law Reform and Criminal Justice Policy.

White R. (2016). Inter-species violence: Humans and the harming of animals. In: Stubbs J and Tomsen S (eds) Australian Violence: Crime, Criminal Justice and Beyond. Sydney: The Federation Press.

White, R. (2015). Environmental victimology and ecological justice. In: Wilson D and Ross S (eds) Crime, Victims and Policy: International Contexts, Local Experiences. Basingstoke: Palgrave Macmillan.

Wyatt, T. (2013). Wildlife Trafficking: A Deconstruction of the Crime, the Victims, and the Offenders. Basingstoke: Palgrave Macmillan.

\section{Journal Articles:}

De Lucia. (2015), Competing narratives and complex genealogies: The ecosystem approach in international environmental law. Journal of Environmental Law, 27 (1).

Donnelly, B. \& Bishop, P. (2007), Natural law and ecocentrism. Journal of Environmental Law, 19 (1), 89.

Flyn, M. \& Hall, M. (2017). The case for a victimology of nonhuman animal harms. Contemporary Justice review, doi:https://doi.org/10.1080/10282580.2017.1348898

Hall, M. (2014). Environmental harm and environmental victims scoping out a 'green victimology'. International Review of Victimology, 20 (1), 129-143.

Herbig J and Joubert S. (2006). Criminological semantics: Conservation criminology vision or vagary ?. Acta Criminologica 19 (3).

Lin A. (2006). The unifying role of harm in environmental law. Wisconsin Law Review 3.

M. J, Lynch, M. J., Mc.Gurrin, D. \& Fenwick, M. (2004). Disappearing act: The representation of corporate crime research in criminological literature. Journal of Criminal Justice, 32(5).

Matthew, P. (2013). Environmental harm and environmental victims: Scoping out a 'green victimology'. International Review of Victimology, 20 (1), 129-143 ${ }^{\text {a }}$ The Author (s) 2013 Reprints and permission: sagepub.co.uk/journalsPermissions.nav doi: 10.1177 / 0269758013508682.

Nurse, A. (2012). Repainting the thin green line: The enforcement of UK wildlife law. Internet Journal of Criminology. Retrieved March 30, 2014, from https://www.internetjournalofcriminology.com/ Nurse_Repainting_The_Thin_Green_Line_IJC_Oct_2012.pdf. 
Olszynski, M. (2005). The Assessment of Environmental Damages Following the Supreme Court's Decision in Canfor. Journal of Environmental Law and Practice, 15(3).

Preston. (2011). The use of restorative justice for environmental crime. Criminal Law Journal, 35.

Schlosberg. (2007). Defining Environmental Justice: Theories, Movements, and Nature. Oxford University Press.

Stone, C. D. (1972). Should trees have standing? Toward legal rights for natural objects. Southern California Law Review, 45, 450-501.

Taylor, R. (2001). A step at a time: New Zealand's progress toward hominid rights. Animal Law Review, 7.

Voiceless. (2009). The animal law toolkit. Available at:www.voiceless.org.au .

Walters, B. (2011). Enlarging our vision of rights: The most significant human rights event in recent times? Alternative Law Journal, 36 (4).

Walters, R. (2006). Crime, bio-agriculture and the exploitation of hunger. British Journal of Criminology, 46 (1).

Wellsmith, M. (2011). Wildlife crime: The problems of enforcement. European Journal on Criminal Policy and Research, 17, 125-148.

White, R. (2013). Environmental Harm: An Eco-Justice Perspective. Bristol Policy Journal.

White, R. (2018). International Review of Victimology. Reprints and permission: sagepub.co.uk/journalsPermissions.nav doi: 10.1177 / 0269758017745615

William, C. (1996). An environmental victimology. Social Science 23 (1): 16-40. Reprinted in: White R (2009) Environmental Crime: A Reader. Cullompton: Willan Publishing.

Williams, C. (2013). Wild law in Australia: Practice and possibilities. Environmental Planning and Law Journal 30. 